\title{
Obraz Jana Chrzciciela w Wyjaśnieniu do Ewangelii Marka Teofylakta z Ochrydy*
}

\section{Image of John the Baptist in Theophylact of Ochrid's The Explanation to the Gospel of Mark}

Słowa klucze: Teofylakt z Ochrydy; Ewangelia Marka; komentarze bizantyjskie; Jan Chrzciciel.

Keywords: Theophylact of Ohrid; Gospel of Mark; byzantine commentaries; John the Baptist.

Streszczenie. Teofylakt z Ochrydy jest autorem pierwszego zachowanego greckiego komentarza do całej Ewangelii Marka. Uznał on Jana Chrzciciela za postać wyróżnioną w tej Ewangelii. Widział w nim ostatniego proroka i początek Ewangelii. Komentarz przedstawia zarówno wyrazową, jak i alegoryczną interpretację wielu fragmentów wzmiankujących Prekursora Jezusa. Rozpoznanie roli Jana Chrzciciela dla szczególnego charakteru tej Ewangelii oraz brak możliwości korzystania z wcześniejszych komentarzy odsłaniają oryginalność egzegezy Teofylakta oraz jego filologiczne i teologiczne kompetencje.

Abstract. Theophylact of Ohrid is the author of the first extant Greek commentary to the entire Gospel of Mark. He considered John the Baptist as a distinctive character in this Gospel. He saw in him the last prophet and the beginning of the Gospel. The commentary offers both literal and allegorical interpretation of many passages mentioning Jesus's Forerunner. The recognizing of the role of John the Baptist for the specificity of this Gospel and impossibility to depend on the previous commentaries reveal the originality of Theophylact exegesis and his philological and theological competences.

* Artykuł na podstawie pracy licencjackiej (licencjat kanoniczny): „Obraz Jana Chrzciciela w Wyjaśnieniu do Ewangelii Marka Teofylakta z Ochrydy. Studium Wirkungsgeschichte Ewangelii” (Wydział Teologiczny Uniwersytetu Śląskiego w Katowicach, promotor ks. dr hab. Artur Malina). 
D awne komentarze do tekstów biblijnych zajmują istotne miejsce wśród źródeł dla teologii. Początkowo były wygłaszane w liturgii w formie homilii, przedstawiane w katechezach jako kazania, w końcu spisywane. Wśród nich niewiele jest komentarzy do Ewangelii Marka ${ }^{1}$. Na przykład wyjaśnienia jej tekstu greckiego autorstwa Jana Chryzostoma ograniczają się do fragmentów Marka (Mk 10,17-27; 14,65) i zamieszczone są w jego komentarzu do Ewangelii Mateusza (PL, 58). Fragmentaryczny Tractatus in Marci Evangelium Hieronima (CCL, 78), a także najwcześniejszy zachowany w całości komentarz, In Marci evangelium expositio (CC SL, 120) autorstwa Bedy Czcigodnego, napisano w łacinie ${ }^{2}$. Nie zachował się żaden starożytny komentarz w języku greckim do całości Ewangelii Marka³, podczas gdy są dostępne całościowe i systematyczne komentarze do Ewangelii Mateusza, Łukasza i Jana ${ }^{4}$. Takiego ciągłego komentarza nie posiadają też niektóre księgi ST, np. Księgi Samuela, Księgi Królewskie czy Księga Aggeusza ${ }^{5}$. Na tym tle komentarz Teofylakta do Ewangelii Marka jawi się jako wyjątkowy ${ }^{6}$ : jest pierwszym zachowanym komentarzem do tej Ewangelii; został napisany po grecku, a więc w tym samym języku, co komentowany tekst; komentarze tego samego autora do Mateusza i Łukasza pozwalają na porównanie jego wyjaśnień tekstów Marka z interpretacjami paralelnych fragmentów w Ewangeliach synoptycznych.

W Przedmowie do Wyjaśnienia do Ewangelii Marka Teofylakt daje uzasadnienie dla zajęcia się Ewangelią Marka w odrębnym komentarzu . Argumentuje pośrednio, wskazując na domagające się interpretacji cechy właściwe dla tej Ewangelii. Już tutaj pojawiają się odniesienia do Jana Chrzciciela, który jest jedyną postacią - oprócz Osób Boskich i Ewangelistów - wspomnianą częściej niż jeden raz. Ta asymetria sugeruje, że jego rola jest dla Teofylakta znacząca. Natomiast w samym tekście Wyjaśnienia znajduje się kilka grup tekstów, w których wzmiankowany jest Jan. Poniższa tabela pokazuje teksty odnoszące się do Jana: zarówno w Ewangelii, jak i w Wyjaśnieniu Teofylakta.

1 Por. P.M. Head, The Early Text of Mark, s. 113.

2 Lista komentarzy do Ewangelii Marka powstałych przed rokiem 1950 w: F. Neirynck, Commentaries Before 1950, s. 701-717.

3 Posiadamy jedynie wyjaśnienia w formie katen. Por. T.C. Oden, C.A. Hall, Wstęp ogólny, s. X.

4 Por. T.C. Oden, C.A. Hall, Wprowadzenie do Komentarza, s. XXVIII.

5 Por. T.C. Oden, C.A. Hall, Wstęp ogólny, s. X.

6 O wartości komentarzy Teofylakta zob. M. Czarnuch, Papuga Złotoustego?

7 Por. M. Czarnuch, Teofylakta uzasadnienie. 


\begin{tabular}{|c|c|}
\hline $\begin{array}{c}\text { Teofylakt przywołuje Jana } \\
\text { w komentarzach do fragmentów Mk: }\end{array}$ & $\begin{array}{c}\text { Marek przywołuje Jana } \\
\text { w następujących wersach: }\end{array}$ \\
\hline $1,1-3$ & 1,4 \\
\hline $1,4-5$ & 1,6 \\
\hline 1,6 & \\
\hline $1,7-8$ & 1,9 \\
\hline $1,9-11$ & 1,14 \\
\hline $1,14-15$ & \\
\hline $1,16-20$ & 2,18 \\
\hline $2,18-20$ & 6,$14 ; 16$ \\
\hline $6,14-16$ & 6,$17 ; 18 ; 20$ \\
\hline $6,17-20$ & 6,$24 ; 25$ \\
\hline $6,21-29$ & 8,28 \\
\hline $8,27-30$ & \\
\hline $9,11-13$ & 11,$30 ; 32$ \\
\hline $11,27-33$ & \\
\hline $13,21-26$ & \\
\hline & \\
\hline & \\
\hline & \\
\hline
\end{tabular}

\section{Analiza fragmentów}

Większość Teofylaktowych wzmianek o Janie odpowiada pojawianiu się Chrzciciela w tekście Ewangelii Marka. Jego osoba i działalność są przedstawiane także w komentarzach do perykop, w których nie pojawia się jego imię. Nie ma jednak przypadku pominięcia go w wyjaśnieniach tekstów wzmiankujących jego obecność.

\subsection{Przedmowa}

Porównując Ewangelie Mateusza i Marka, Teofylakt zauważa, że ich treść jest podobna (choć u Mateusza została przedstawiona obszerniej). Najbardziej znaczące różnice można dostrzec na ich początku: Mateusz rozpoczął Ewangelię od narodzenia Jezusa, a Marek - od Jana. Prekursor zostaje tutaj po raz pierw- 
szy nazwany prorokiem i ta jego rola jest uwydatniona w dalszej części Przedmowy. Komentator uznaje zatem Jana Chrzciciela za postać charakterystyczną dla Drugiej Ewangelii.

Potwierdzeniem dla tego wyróżnienia jest symboliczna interpretacja treści czterech Ewangelii, oparta na zestawieniu ich z czterema istotami żyjącymi ${ }^{8}$. Skojarzenia oparte są na porównaniu cech każdej z istot oraz początku każdej Ewangelii. W ten sposób połączony zostaje królewski lew z królewskim Słowem z Prologu Jana. Człowiek odpowiada otwierającej Ewangelię Mateusza genealogii, czyli ludzkiemu pochodzeniu Chrystusa. Orzeł, widzący wyraźnie $\mathrm{z}$ daleka, zestawiony jest $\mathrm{z}$ rozpoczynającym Ewangelię Marka prorokiem Janem, natomiast wół odpowiada Ewangelii Łukasza, którą rozpoczyna składana z wołu ofiara Zachariasza. W ten sposób Teofylakt po raz drugi wskazuje na Jana jako postać znaczącą w Ewangelii Marka.

Biskup Ochrydy przejął zestawienie istot żyjących z Ewangeliami od Ireneusza $\mathrm{z}$ Lyonu, jednak porównanie argumentacji obu komentatorów pozwala dostrzec oryginalny element w Teofylaktowym obrazie Jana. Obaj zestawiają Ewangelię Marka z orłem, nawiązując do łaski prorokowania. Jednak o ile Ireneusz w tym miejscu przywołuje Izajasza, o tyle Teofylakt łaskę proroctwa odnosi do Jana Chrzciciela, widząc go jako ostatniego z proroków ${ }^{9}$.

\subsection{Mk 1,1-3}

O uznanej przez Teofylakta roli Jana Chrzciciela świadczy wyjaśnienie pierwszych trzech wersetów Ewangelii. Brak oddzielenia pierwszego od dwóch następnych ${ }^{10}$. Komentując je razem, Teofylakt podporządkowuje znaczenie

8 Symbolika czterech istot żyjących wykorzystana jest w Księdze Ezechiela (Ez 1,5-6.10), w opisywanej przez proroka wizji chwały Bożej. Ezechiel widzi cztery istoty żyjące, a każda z nich ma cztery twarze: człowieka, lwa, cielca i orła. Nieco odmienny obraz pojawia się w Apokalipsie (Ap 4,6-7). Barankowi oddają chwałę cztery istoty: lew, wół, człowiek oraz orzeł.

9 Teofylakt korzystał z tekstu bizantyjskiego, który - wraz z kodeksami Aleksandryjskim i Waszyngtońskim - ma lekcję „jak zostało napisane u proroków”. Natomiast najważniejsze greckie kodeksy majuskułowe (Synajski, Watykański), a także Peszitta i przekłady koptyjskie mają wersję: „jak zostało napisane u Izajasza proroka”, która łączy Jana jedynie z Izajaszem.

10 Komentarze do Marka, które uznają pierwszy werset za tytuł całej Ewangelii: A. Stock, The Method and Message of Mark, s. 43; K. Stock, Marco, s. 19; komentarze traktujące pierwszy werset jako tytuł prologu: J. Gnilka, Marco, s. 35-37; R.H. Gundry, Mark, s. 30-33; W. Hendriksen, The Gospel of Mark, s. 32-33; dyskusję o funkcji Mk 1,1 zwięźle przedstawia: S. Légasse, Marco, s. 58-61. 
pierwszego wersu treści wydobytej z całego fragmentu. Biskup Ochrydy traktuje go jako wprowadzenie do cytatów z proroków. Znaczeniu osoby i dzieła Jana Chrzciciela poświęcona jest większość komentarza tego fragmentu. Zajmując się trzecim wersetem, komentator ogranicza się do przedstawienia znaczenia miejsca działalności Jana.

Komentowanie trzech pierwszych wersów Ewangelii Marka łącznie, tak jak czyni to Teofylakt, może być uzasadnione ich treścią ${ }^{11}$. W odróżnieniu od kolejnych wersetów, w których rozpoczyna i rozwija się narracja, trzy pierwsze są jakby metahistoryczne. Markową kombinację biblijnych cytatów ${ }^{12}$ Teofylakt odczytuje Jako wypowiedź Ojca do Syna o Janie.

Łączenie pierwszego wersetu $\mathrm{z}$ następnymi dwoma, a tym samym traktowanie czwartego jako początku relacji o Janie, tak jak to czyni Teofylakt, jest potwierdzone przez część manuskryptów, które zmieniają składnię pierwszych czterech wersetów: oddzielając opowiadanie o wystąpieniu Jana spójni-

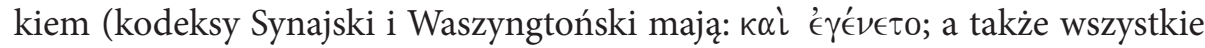
przekłady syryjskie oraz koptyjskie mają spójniki odpowiadające zwrotowi:

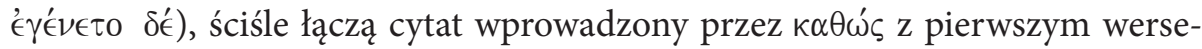
tem. Na łączenie słów o początku Ewangelii z kombinacją cytatu z proroków musiała wpłynąć obecność nagłówka: „[Ewangelia] według Marka”. Czytający rękopisy z tym dodatkiem niepochodzącym od Ewangelisty nie mogli przypisać zdaniu pochodzącemu od samego autora pełnej funkcji tytułu, gdyż wówczas księga miałaby dwa tytuły.

Struktura tego fragmentu w Wyjaśnieniu oparta jest na kolejnych frazach Marka, wyjaśnianych przez Teofylakta. Koncentrują się one na dwóch wątkach: Jana jako Prekursora oraz Starego i Nowego Przymierza.

Teofylakt nazywa Jana ostatnim z proroków i początkiem Ewangelii Syna Boga. Zauważa, że do niego odnoszą się dwa cytaty z proroków, umieszczo-

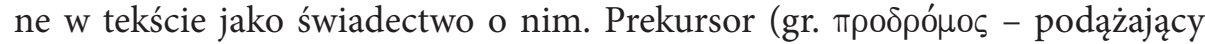

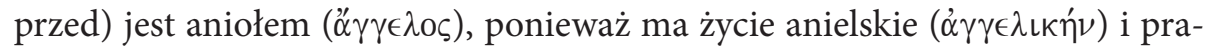
wie niematerialne oraz ponieważ ogłasza $\left(\dot{\alpha} \gamma \gamma^{\prime} \epsilon \lambda \lambda \epsilon \iota\right)$ i objawia przychodzącego Chrystusa. W ten sposób Teofylakt wyprowadza dwa sensy ze słowa „anioł”. Występują one w języku greckim. Podstawowe znaczenie jest obecne w tek-

11 Z drugiej strony za oddzieleniem pierwszego wersetu od dwóch następnych przemawia brak formy czasownikowej. Na połączenie Mk 1,2-3 z tym, co następuje, wskazuje obecność wspólnych motywów: pustyni, drogi oraz obecność wezwania Jana do zmiany życia (w odniesieniu do drogi i ścieżek).

12 Pochodzą one przynajmniej z dwóch ksiąg Starego Testamentu: pierwsza część z Ml 3,1, która jest łączona z Wj 23,20, a druga z Iz 40,3. 
stach biblijnych ${ }^{13}$. Na niecielesność aniołów biskup Ochrydy wskazuje w komentarzu do odpowiedzi Jezusa danej saduceuszom na temat zmartwychwsta-

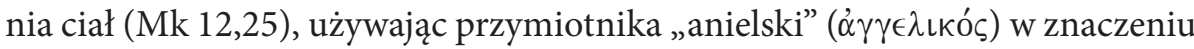

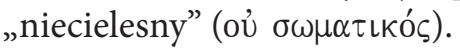

Teofylakt wyjaśnia, w jaki sposób można odnieść do Jana słowa o tym, że przygotował drogę Pana. Udzielając chrztu, przysposobił dusze Żydów na Jego przyjęcie. To, że jest wysłany „przed obliczem”, określa jego bliskość: jak najbliżsi krewni idą przed królami, tak pozycja Prekursora wskazuje na bliskość Chrystusa. W zwrocie: „głos wołającego na pustyni”, odniesionym do Jana, „pustynię" rozumie Teofylakt na dwa sposoby: jako pustynię (miejsce pustynne) Jordanu, gdzie przebywał Jan, albo jako synagogę Żydów, określoną jako „pustkowie każdego dobra” (w dalszej części Ewangelii Marka obraz wszystkich Żydów jest raczej negatywny: tutaj jednak wszyscy wychodzą do Jana; są chrzczeni wyznając swoje grzechy). Będąc jednocześnie ostatnim ( $\tau \in \lambda \in U \tau \alpha i ̂ \varsigma)$

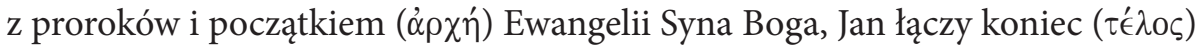

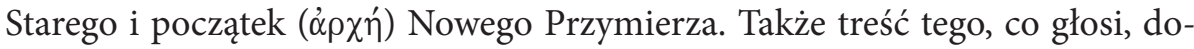
tyczy ich obu. Podwójne wezwanie - „Gotujcie drogę Panu, prostymi czyńcie ścieżki jego” - Teofylakt odczytuje alegorycznie. Drogą jest Nowe Przymierze trzeba, aby zostało przygotowane. Ścieżki zaś to Stare Przymierze. Ono istnieje, ale jest zniszczone, trzeba więc uczynić je równym. Ci, którzy przyjęli Stare Przymierze, są z tego powodu „nierówni” i chromi.

Komentując pierwsze zdanie Ewangelii Marka: „Początek Ewangelii Jezusa Chrystusa, Syna Boga", Teofylakt pisze, że to Jan jest początkiem Ewangelii Syna Boga. Faktycznie, tekst Ewangelii Marka pozwala na interpretację łączącą „początek Ewangelii" z okresem działalności Jana ${ }^{14}$. Jednak biskup Ochrydy idzie krok dalej, kiedy wskazuje, że to osoba Jana jest tym początkiem. Ten fragment

13 We wcześniejszych tekstach Starego Testamentu występuje niewiele wzmianek o aniołach. Dopiero w źródłach redagowanych po niewoli babilońskiej, które wyrażały jednoznacznie wiarę w jedynego Boga i fałszywość wierzeń w innych bogów, zaczęto przypisywać aniołom większą rolę. Ich funkcja pośredników między Bogiem a ludźmi pozwalała akcentować transcendencję Boga Izraela (Rdz 16,7-11; 21,17; 22,11.15; 31,11; Wj 3,2; $14,19)$. W tej roli występują jako Boży posłańcy, którzy zwiastują Jego wolę, plany i zamiary względem ludzi (Sdz 6,11-24; 13,3-25). Rzeczownik w znaczeniu podstawowym „posłańca”, „wysłannika” występuje w paradoksalnym określeniu, jeśliby je tłumaczyć dosłownie: „anioł szatana” (2 Kor 12,7). Drugie znaczenie odnoszące się do duchowego, niematerialnego bytowania aniołów wynika $\mathrm{z}$ ich jeszcze bardziej podstawowej roli przypisanej im w angelologii biblijnej: znajdują się oni na dworze niebieskim i oddają cześć Bogu. Ta funkcja duchowych bytów przeznaczonych do kultu jest zaakcentowana w jedynej biblijnej definicji (Hbr 1,14); por. A. Malina, Jezus i ksiegi Nowego Testamentu o aniołach, s. 19-37.

14 Por. J. Gnilka, Marco, s. 40. 
komentarza odsłania pełniejsze znaczenie porównania Mateusza i Marka zamieszczonego w Przedmowie. Teofylakt zauważa różnicę między tymi Ewangeliami w ich początku. Mateusz rozpoczyna się od narodzenia Jezusa według ciała, a Marek od pojawienia się Jana. Podobnie postępuje, przedstawiając znaczenie symboliki czterech istot żyjących. Chociaż zaczerpnął ją od innych autorów (np. Ireneusza z Lyonu), to jednak w swoim wyjaśnieniu posługuje się często czasownikiem „rozpocząć”, oznaczającym różnicę między Ewangeliami. Czasownik ten w języku greckim, podobnie jak w języku polskim, ma tę samą podstawą wyrazową, co rzeczownik „początek”, który otwiera komentowaną przez Teofylakta Ewangelię.

Ponadto, nazwanie Jana początkiem Ewangelii Syna Boga ma jeszcze jeden aspekt. W komentowanym fragmencie każda ze wzmianek o Janie połączona jest z osobą Chrystusa. Jan, ostatni z proroków, jest początkiem Ewangelii Syna Boga. Prekursor ogłasza i objawia przychodzącego Chrystusa. Jan przygotował drogę Pana, a bliskość Prekursora wskazuje na Chrystusa. Teofylakt przedstawia $\mathrm{w}$ ten sposób swoje rozumienie relacji Jana do Jezusa.

\subsection{Mk 1,4-5}

Fragment w całości jest poświęcony działalności Jana. Koncentracja ta odpowiada treści dwóch kolejnych wersetów. Teofylakt łączy je w komentarzu, choć werset czwarty opisuje sumarycznie całą działalność Jana jako udzielanie chrztu na pustyni i głoszenie chrztu nawrócenia na odpuszczenie grzechów ${ }^{15}$. Natomiast w wersecie piątym znajduje się opis adresatów tej działalności: ich wychodzenia $\mathrm{z}$ miejsc zamieszkania oraz przyjmowania chrztu w Jordanie z wyznawaniem ich grzechów. Forma gramatyczna czasowników „wychodzić”

15 Na sumaryczny charakter opisu działalności Jana wskazuje jego zwięzłość i symetryczność w rozwinięciu jej przedstawienia w następnych czterech wersetach. Dwuczęściowy opis jest podany w dwóch paralelnych częściach odnoszących się do działalności Jana mających za oś charakterystykę jego życia. Najpierw narrator ukazuje, że celem udzielania przez Jana chrztu jest wyznanie grzechów $(\mathrm{Mk} 1,5)$. Następnie przez charakterystykę ubioru i pożywienia Jana pokazuje, że całe jego życie było związanie z pustynią: miejscem, gdzie ludzie rozpoznawali potrzebę naprawy ich relacji do Boga (Mk 1,6). W końcu przedstawia w mowie niezależnej treść głoszenia chrztu nawrócenia na odpuszczenie grzechów, w której ten chrzest jest identyfikowany z chrzczeniem w Duchu Świętym (1,7-8). Oznaczenie pojawienia się osoby dokonującej przyszłego chrzczenia przez czasownik „przychodzi” ('€ $\rho \chi \in \tau \alpha \iota)$ ma podwójną funkcję: z jednej strony wskazuje na szerszy kontekst cytatu z Deuteroizajasza zawierającego zapowiedź przyjścia Boga z mocą jako treść Dobrej Nowiny (Iz 40,9-10), z drugiej zaś strony proleptycznie odnosi się do następnego wersetu ukazującego przyjście Jezusa nad Jordan: „I przyszedł Jezus z Nazaretu Galilei” (Mk 1,9). 
oraz „przyjmować chrzest” (czas przeszły niedokonany) łączy ten werset z następnym, zawierającym tę samą formę czasownika „być”, ale dotyczącą Jana. Natomiast werset czwarty ma orzeczenie „stać się”, „pojawić się” w trybie

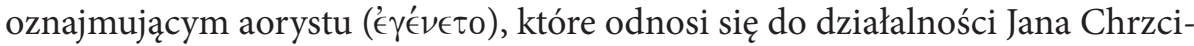
ciela ujętej całościowo.

Chociaż Teofylakt przytacza dwa wersety razem, nie zajmuje się szczegółowo wersetem piątym. Ich połączenie może wynikać z traktowania prezentacji wychodzenia ludzi jako reakcji na działanie Jana (przedstawione w wersecie czwartym). W tych dwóch wersetach zawarta jest ogólna charakterystyka aktywności ludzi, a następny werset zawiera szczegółowy opisu ubioru i diety Jana, na poziomie sensu wyrazowego ${ }^{16}$ nieodnoszący się wprost do adresatów jego działalności.

Tekst bizantyjski komentowany przez Teofylakta różni się od wersji przyjętej w najnowszych wydaniach krytycznych. Podczas gdy one mają zdanie: „I wychodziła do niego cała Judzka kraina i mieszkańcy Jerozolimy wszyscy i byli chrzczeni przez niego w rzece Jordan, wyznając swoje grzechy", bardziej rozpowszechniona wersja tekstu bizantyjskiego ma wariant: „I wychodziła do niego cała judzka kraina i mieszkańcy Jerozolimy i byli chrzczeni wszyscy w rzece Jordan przez niego wyznając swoje grzechy”. Zmieniona pozycja przymiotnika „wszyscy” powoduje, że lekcja tekstu większości manuskryptów ukazuje całą krainę judzką jako adresatów chrztu Janowego, ale wśród nich nie przedstawia wszystkich mieszkańców Jerozolimy, tak jak to sugeruje tekst poświadczony przez lepsze rękopisy ${ }^{17}$.

Wyjaśnienie Teofylakta ma za przedmiot tekst grecki. Na przykładzie komentarza do Mk 1,4 widać bardzo dobrze korzyści z lektury tekstu w jego oryginalnej postaci. Liczni komentatorzy od starożytności nie zauważali, że Marek charakteryzuje Jana jako chrzczącego i głoszącego. Teofylakt nie utożsamia pierwszego imiesłowu z tytułem „Chrzciciel”, tak jak to ma miejsce w tych licznych komentarzach ${ }^{18}$. Przedstawia, tak jak Ewangelista, te dwie aktywności

16 Jednak, komentując Mk 1,6 wyprowadza dwa sensy z opisu ubioru i diety Jana: wyrazowy i alegoryczny. Ten drugi odnosi do adresatów działalności Jana.

17 Kodeksy Synajski, Watykański i Regius oraz niektóre łacińskie z V i VI wieku.

$18 \mathrm{Na}$ obecność formy czasownikowej zwracają uwagę niektórzy z komentujących Mk 1,4, ale ani nie oddają jej w tłumaczeniu, ani nie przypisują działalności chrzcielnej Jana rangi odpowiadającej jego aktywności kerygmatycznej. Brak rozróżnienia dwóch wymiarów działalności Jana prowadzi do utożsamienia chrztu udzielanego przez niego ze chrztem przez niego głoszonym, czyli do przypisania obmyciu dokonywanemu przez Chrzciciela mocy odpuszczania grzechów. Tego błędu nie popełnia Teofylakt właśnie dlatego, że zauważa dwa równorzędne rodzaje aktywności Jana. Błędnie np.: J. Gnilka, Das Evangelium nach Markus, s. 40; W. Grundmann, Das Evangelium nach Markus, s. 34; H. Langkam- 
Jana na jednym poziomie, jako sobie odpowiadające. Chociaż w tekście Marka przedmiotem głoszenia przez Jana jest chrzest nawrócenia na odpuszczenie grzechów, to jednak Teofylakt stwierdza, że chrzest Jana nie uwalniał od grzechów. Trafnie wyjaśnia relację między głoszeniem przez Jana chrztu nawrócenia a odpuszczeniem grzechów. Ten pierwszy jest ukierunkowany na przyjęcie Chrystusa. Dopiero to przyjęcie, którego warunkiem jest nawrócenie, daje odpuszczenie.

\subsection{Mk 1,6}

Odrębny fragment komentarza w całości poświęcony jest złożonemu zdaniu z Ewangelii Marka, charakteryzującemu ubiór i pokarm Jana. Jednak Teofylakt w drugiej połowie wyjaśnienia nie zajmuje się bezpośrednio Prekursorem, nadając alegoryczne znaczenie pokarmowi Jana. Szarańczę przedstawia jako symbol duchowego pokarmu narodu. Porównuje jej sposób poruszania się do kondycji religijnej i moralnej narodu żydowskiego, mającej swoje duchowe wzloty i upadki. Natomiast miód jest dla Teofylakta symbolem nauczania proroków. Jak miód leśny nie jest owocem pracy pszczelarzy, tak też Żydzi nie zabiegali o dobrodziejstwa płynące z nauczania proroków.

Teofylakt odzienie i pokarm Jana interpretuje paralelnie. Każde z nich odnosi najpierw do samego Jana, a potem do Żydów: w sensie wyrazowym - do Jana, a w alegorycznym - do Żydów. Identyfikuje ubiór Jana jako charakterystyczny dla proroka. Jednak nie porównuje Jana z jakimś określonym prorokiem, chociaż wzmianka w tekście Marka o pasie skórzanym mogłaby wywołać skojarzenie z podobnie ubranym Eliaszem $(2 \mathrm{Krl} \mathrm{1,8})^{19}$. Pojawia się pytanie, dlaczego Teofylakt nie wiąże $\mathrm{w}$ tym miejscu działalności Jana $\mathrm{z}$ działalnością Eliasza. Można było zauważyć już we wcześniejszej części Wyjaśnienia, że Teofylakt nie traktuje Jana jako jednego z proroków (zob. komentarz do Mk 1,1-3). Tutaj biskup Ochrydy postępuje konsekwentnie, przedstawiając odzienie Jana jako znak wszystkich proroków.

Interpretację uzupełnia o elementy egzegezy alegorycznej. Ubiór Jana jest symbolem żałoby, gdyż - jak pisze - Jan pokazywał, że „nawracający się powinien smucić się" ( $\pi \in \nu \theta \epsilon i ̂)$. Natomiast pokarm „przedstawia wstrzemięźliwość

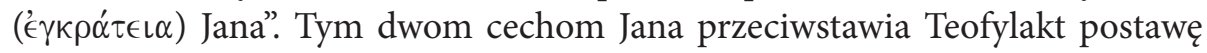

mer, Ewangelia wedtug św. Marka, s. 80; J. Mateos, D. Camacho, Il Vangelo di Marco, s. 72; F.J. Moloney, The Gospel of Mark, s. 33; C.S. Rodd, The Gospel of Mark, s. 4.

19 W ten sposób m.in.: H. Langkammer., Ewangelia według św. Marka, s. 82. Także liczne wydania Nowego Testamentu identyfikują opis odzienia Jana jako aluzję do ubioru Eliasza - np. przez oznaczenie na marginesie Mk 1,6 w Novum Testamentum Graece, ad loc. 
Heroda, kiedy komentuje fragmenty odnoszące się do władcy Galilei (Mk $6,14-16 ; 6,17-20 ; 6,21-29)$.

\subsection{Mk 1,7-8}

Fragment poświęcony jest dwóm wersetom Ewangelii Marka przedstawiającym kerygmatyczną działalność Jana, a mianowicie przyjście osoby przewyższającej Prekursora oraz rozróżnienie dokonane przez niego między chrztem „W wodzie" a chrztem „w Duchu Świętym”.

Krótki komentarz do dwóch wersetów poświęca znaczeniu czynności rozwiązywania rzemieni sandałów. Nie zwraca uwagi w tym miejscu na relację między Janem a Jezusem wynikającą z pozycji Mesjasza przychodzącego po Prekursorze $^{20}$. Pomija także sens określenia Mesjasza jako mocniejszego. Teofylakt nie zauważa różnicy między „chrztem wodą” a chrztem „w Duchu Świętym". Wynika to z faktu, że korzysta on z tekstu bizantyjskiego, który charakteryzował działalność chrzcielną Jana oraz osoby przez niego zapowiedzianej za pomocą konstrukcji posiadającej ten sam przyimek „W” ('€v). W tekście poświadczonym przez lepsze rękopisy przyimek ten występuje tylko w charakterystyce drugiego chrzczenia: „Ja chrzciłem was wodą, on zaś chrzcił będzie was w Duchu Świętym” (Mk 1,8) ${ }^{21}$. Natomiast w rękopisach bizantyjskich zdanie brzmi: „Ja chrzciłem was w wodzie, on zaś chrzcił będzie was w Duchu Świętym". Jeśli nawet obecność przyimka może wydawać się nieistotna, to jednak w działalności Jezusa - tak jak ją przedstawia Marek - pojawia się on zarówno jako określenie relacji ludzi do duchów nieczystych (Mk 1,23; 3,22; 5,2), jak i w kwalifikacji władzy Jezusa (Mk 11,28-29.33).

Alegorycznie identyfikując rzemienie sandałów z grzechami, Teofylakt odnosi się do fragmentu poprzedzającego, który przedstawia ich wyznanie przez adresatów działalności Jana. Tłumaczy rozwiązywanie rzemieni sandałów przez Jana jako działanie zmierzające do odpuszczenia grzechów przez wiarę w Chrystusa. Jednocześnie wyjaśnia, dlaczego zadaniem Jana nie jest rozwiązanie rzemienia sandałów Przychodzącego. W ten sposób odnosi się już do fragmentu następującego, który przedstawia przyjście Jezusa, u którego - według tej alegorycznej interpretacji - Jan nie znalazł rzemienia do rozwiązania,

20 Pisał o tym już wcześniej, wzmiankując o Janie w czterokrotnym odniesieniu do Chrystusa (zob. komentarz do Mk 1,1-3).

21 Kodeksy Synajski i Koridethi oraz niektóre starołacińskie; także niektóre manuskrypty zaliczane do świadków tekstu bizantyjskiego mają lekcję bez tego przyimka przed rzeczownikiem „woda”: kodeksy Guelferbytanus (VI w.) oraz Cyprius i Campianus (obydwa z IX w.). Natomiast Kodeks Watykański opuszcza przyimek w obydwu przypadkach. 
którym byłby grzech. Teofylakt, podobnie jak wielu czytelników Ewangelii i jej komentatorów w starożytności ${ }^{22}$, musi zmierzyć się z trudnościami wynikającymi z następnej perykopy.

\subsection{Mk 1,9-11}

Następny fragment komentowany przez Teofylakta to relacja o chrzcie Jezusa przyjętym od Jana i następująca po nim teofania. Biskup Ochrydy - podobnie, jak Ewangelista - zwraca uwagę na Jezusa, a Janem zajmuje się w mniejszym stopniu. Rolę Chrzciciela podporządkowuje wyjaśnieniu przyjścia Jezusa na chrzest w rzece Jordan oraz niektórych elementów teofanii.

Komentator starannie argumentuje: w pierwszym fragmencie wyjaśnia, co nie było celem przyjścia Jezusa, natomiast w drugim przedstawia ten cel. Nie chodziło w nim o odpuszczenie Jego grzechów, ponieważ, jak już to dobitnie wyraził wcześniej Teofylakt, chrzest Jana nie miał takiej mocy. Takim celem nie mogło być także otrzymanie Ducha, gdyż, zgodnie z argumentacją biskupa Ochrydy, chrzest, który nie odpuszcza grzechów, nie może Go udzielać. Teofylakt akcentuje także wątek pominięty wcześniej (w analizie Mk 1,7-8), podkreślając, że Jezus, już przychodząc nad Jordan, jest mocniejszy od Chrzciciela.

Po argumentacji negatywnej Teofylakt przedstawia rację przyjścia Jezusa. W tym miejscu nie sięga do tekstu Marka, ale do Czwartej Ewangelii. W perykopie paralelnej bowiem Chrzciciel sam określa cel: „aby on został objawiony Izraelowi” (J 1,31). Warto zwrócić uwagę na interpretację formy pasywnej w komentarzu Teofylakta. Podczas gdy w Czwartej Ewangelii ta forma może być rozumiana jako passivum theologicum ${ }^{23}$, to znaczy sprawcą objawienia

22 O trudnościach interpretacyjnych świadczy już pomniejszanie roli Jana jako chrzczącego Jezusa w tradycji ewangelicznej: w Ewangelii Mateusza pojawia się dialog uzasadniający przyjęcie od Jana chrztu przez Jezusa (Mt 3,14-15); Łukasz wzmiankuje o aresztowaniu Jana przed przyjściem Jezusa nad Jordan (Łk 3,20); w Czwartej Ewangelii nie ma w ogóle wzmianki o chrzcie Jezusa, a tylko pojawia się świadectwo o teofanii (J 1,29-34). Późniejsza tradycja apokryficzna wprowadza własne elementy wzmacniające tę tendencję relatywizującą przyjęcie chrztu przez Jezusa. Ewangelia Ebionitów, 5: „I wtedy Jan [...] padłszy przed Nim rzekł: «Błagam Cię, Panie, ochrzcij mnie». Ten jednak sprzeciwił się mówiąc: «Przestań, ponieważ w ten sposób trzeba, aby się wszystko wypełniło». Ewangelia Nazarejczyków, 25a: „Oto matka Pana i bracia Jego tak mu powiedzieli: «Jan Chrzciciel chrzci na odpuszczenie grzechów: chodźmy więc, by nas ochrzcił». A on odpowiedział: «W czym zgrzeszyłem, abym miał iść i otrzymać od niego chrzest? Chyba że z nieświadomości coś powiedziałem» (Apokryfy Nowego Testamentu, s. 73.79).

23 Następne trzy wersety wypowiedzi Jana Chrzciciela w Czwartej Ewangelii nie pozostawiają żadnej wątpliwości, że podmiotem objawiającym - najpierw Janowi, a następnie przez jego świadectwo Izraelowi - tożsamość i cel działalności Jezusa jest Bóg Ojciec. 
Jezusa jest Bóg, biskup Ochrydy wydaje się rozumieć czasownik „objawić” w sensie słabym, to znaczy „wskazać”. Pisze on bowiem, że Jezus przychodzi, „by został objawiony przez Jana ludowi”.

Z tego powodu też prawdopodobnie korzysta $z$ Mateuszowej wersji słów głosu z nieba skierowanych do Jezusa. W Pierwszej Ewangelii głos z nieba oznajmia: „To jest Syn mój” (Mt 3,17). Zdanie to może być rozumiane jako objawienie tożsamości Jezusa obecnym nad Jordanem. W ten sposób Teofylakt interpretuje osiągnięcie wcześniej wskazanego celu udzielenia chrztu Jezusowi: aby on został objawiony przez Jana ludowi. W Ewangelii Marka słowa głosu z nieba mają formę wyznania skierowanego bezpośrednio do Jezusa: „Ty jesteś Syn mój umiłowany" (Mk 1,11). Chociaż Teofylakt oddala się od tekstu Marka, to jednak komentując tę perykopę pokazuje, że czyta ją uważnie w brzmieniu oryginalnym. Przyjęcie zdania głosu z nieba $\mathrm{w}$ formie objawienia tożsamości Jezusa ludowi („To jest mój Syn” zamiast „Ty jesteś moim Synem”) rodzi trudność w identyfikacji osoby, do której odnoszą się te słowa. Teofylakt zajmuje się tym problemem. Zwraca uwagę na znaczenie zstępowania Ducha na Jezusa, a nie na wzmiankę o gołębicy. Faktycznie, w tekście Marka (a także Mateusza i Jana) Duch Święty nie jest porównany z gołębicą, ale Jego zstępowanie z lotem gołębicy. Celem tego porównania - zgodnie z intencją Ewangelisty - jest wskazanie na adresata słów głosu z nieba. Adresata oznacza przyimek identyfikujący kres zstępowania Ducha. Teofylakt słusznie zauważa, że zstępowanie Ducha jest ściśle powiązane $\mathrm{z}$ wyznaniem głosu $\mathrm{z}$ nieba ${ }^{24}$.

\subsection{Mk 1,14-15}

Kolejny fragment komentarza, w którym pojawia się odniesienie do Jana Chrzciciela, dotyczy wystąpienia Jezusa w Galilei. W Ewangelii Marka między relacją o chrzcie Jezusa a opowiadaniem o początku Jego publicznej działalności znajduje się zwięzła narracja o czterdziestodniowym pobycie Jezusa na pustyni. Teofylakt nie szuka w niej żadnych treści, które mogłyby odnosić się do Jana.

W Ewangelii Marka wzmianka o Janie jest bardzo krótka („Po wydaniu Jana przyszedł Jezus...”). Teofylakt rozwija jednak odniesienie do Chrzciciela. Najpierw interpretuje wyjście Jezusa jako oddalenie się od miejsca prześlado-

24 Porównanie zstępowania Ducha Świętego w Mk 1,10 do zniżania się gołębicy pełni precyzyjną funkcję w narracji: zstępujący nie ogarnia wielu ludzi, ale schodzi wyłącznie do Jezusa. To doprecyzowanie ma znaczenie dla wyraźnego określenia adresata deklaracji głosu z niebios w Mk 1,11, którym nie jest ani Izrael, ani Jan Chrzciciel, lecz tylko Jezus; por. A. Malina, Chrzest Jezusa w czterech Ewangeliach, s. 261. 
wania Jana i traktuje to jako wzór postępowania dla chrześcijan. Następnie zestawia ze sobą treści głoszone przez Jana i Jezusa.

Obydwa odniesienia do Jana (o aresztowaniu i o treści kerygmatu) mają strukturę porównania służącego parenezie. W pierwszym Jezus jest wzorem dla chrześcijan w obydwu znaczeniach: jako ten, który ucieka od prób (dosłownie: pokus), a nie wychodzi im naprzeciw, oraz jako ten, który we wcześniejszej scenie (kuszenia) poddany próbom, je znosił. Takie zestawienie budzi skojarzenie $\mathrm{z}$ Janem znoszącym próbę prześladowań.

Ponadto w tym fragmencie znajduje się przykład tego, jak najczęściej czytana w liturgii i wyjaśniana przez ojców Kościoła Ewangelia wpływa na komentarze do innych Ewangelii. Teofylakt utożsamia kerygmat Jana Chrzciciela z kerygmatem Jezusa. W Ewangelii Marka jedyne słowa Prekursora przytoczone w mowie niezależnej dotyczą Tego, który przychodzi po nim, oraz Jego wyższości. Tylko w Pierwszej Ewangelii słowa Jana Chrzciciela „Nawracajcie się, zbliżyło się bowiem królestwo niebieskie” (Mt 3,2) są powtórzone przez Jezusa na początku Jego publicznej działalności (Mt 4,17). Teofylakt nie zależy niewolniczo od Mateusza, gdyż nie pisze o „królestwie niebios” (czyli o określeniu występującym bardzo często w Pierwszej Ewangelii), lecz posługuje się wypowiedzią zawartą u Marka: „Zbliżyło się królestwo Boga”.

\subsection{Mk 1,16-20}

Kolejna wzmianka o Janie występuje $\mathrm{w}$ narracji o powołaniu pierwszych uczniów. W tekście Marka brak jakiegokolwiek wyraźnego odniesienia do Jana Chrzciciela. Jednak Teofylakt przywołuje go w początkowej części komentarza, charakteryzując powołanych jako uczniów Jana Prekursora.

W komentarzu znajdują się trzy odniesienia do Jana: Piotr i Andrzej są byłymi uczniami Prekursora. Najpierw świadectwo Jana jest przyczyną pójścia pierwszych uczniów do Jezusa, z kolei jego aresztowanie jest przyczyną ich odejścia od Niego i powrotu do zawodu.

W tym fragmencie po raz drugi Teofylakt komentuje tekst Marka posługując się informacjami pochodzącymi z Czwartej Ewangelii. To z niej bowiem pochodzą dwa pierwsze elementy: Piotr i Andrzej jako uczniowie Jana (J 1,40-41) oraz świadectwo Jana jako przyczyna pójścia jego uczniów za Jezusem (J 1,35). Przez harmonizację dwóch Ewangelii Teofylakt usiłuje uzasadnić, dlaczego występują w nich opisy dwóch powołań pierwszych uczniów. Opowiadanie o wezwaniu Piotra i Andrzeja w Czwartej Ewangelii (J 1,39.42) różni się od narracji o powołaniu ich do podążania za Jezusem, zawartej w Ewangelii Marka (Mk 1,16-20). Teofylakt tłumaczy to odejściem uczniów od Jezusa spowodo- 
wanym aresztowaniem Jana i koniecznością ponownego ich wezwania. Ewangelie nie zawierają żadnej informacji o takim odejściu uczniów od Jezusa.

\subsection{Mk 2,18-19}

Kolejna wzmianka o Janie Chrzcicielu pojawia się w komentarzu do perykopy o niezachowywaniu postów przez uczniów Jezusa. Komentarz Teofylakta dzieli ją na dwie części. Najpierw analizuje wersety przedstawiające okoliczności zarzutów faryzeuszów, samą krytykę przeciwników Jezusa oraz Jego odpowiedź o Oblubieńcu (Mk 2,18-20). Następnie przytacza dwa wersety zawierające logion Jezusa o starych i nowych rzeczach i podaje krótsze wyjaśnienie na ten temat (Mk 2,21-22).

Wzmianka o Janie Chrzcicielu pojawia się tylko w komentarzu do pierwszej części w charakterystyce jego uczniów jako tych, którzy zachowywali żydowskie zwyczaje z powodu braków w ich formacji. Teofylakt szczegółowo komentuje przedstawioną przez Marka relację między Jezusem a Jego uczniami na wzór relacji między oblubieńcem a uczestnikami wesela. Chociaż obraz oblubieńca mógłby być okazją do powołania się na Jana Chrzciciela (w J 3,29 Jan Chrzciciel przedstawia się jako przyjaciel oblubieńca, aby ukazać swoją pozycję w relacji do Jezusa), to jednak biskup Ochrydy nie wykorzystuje tego motywu.

\subsection{Mk 6,14-16}

W Ewangelii Marka między wzmianką o zachowujących posty $(2,18)$ a relacją o opiniach ludzi na temat Jezusa $(6,14.16)$ nie ma żadnego wyraźnego odniesienia do Jana Chrzciciela. Pojawiają się jednak adresaci jego działalności: Marek ukazuje mieszkańców Judei i Jerozolimy jako wychodzących z miejsc zamieszkania, przyjmujących chrzest od Jana i wyznających swoje grzechy (Mk 1,5). W sumarycznym opisie aktywności Jezusa nad brzegiem Jeziora Galilejskiego, Ewangelista wymienia miejsca pochodzenia licznego tłumu, wśród których wylicza Judeę i Jerozolimę (Mk 3,7-8). Następnie Marek przedstawia miejsce pochodzenia uczonych w Piśmie, którzy oskarżają Jezusa o związki z Belzebubem: $\mathrm{z}$ tym zarzutem przychodzą z Jerozolimy (Mk 3,22).

Teofylakt, komentując te dwa fragmenty o przybyłych z Jerozolimy wśród adresatów działalności Jezusa, pomija możliwe odniesienia do Jana Chrzciciela $^{25}$, chociaż, wyjaśniając perykopę niewzmiankującą o nim (Mk 1,16-20),

25 Podobnie czyni w wyjaśnieniu perykopy o faryzeuszach i uczonych w Piśmie przybyłych z Jerozolimy, którzy oskarżają uczniów o niezachowywanie tradycji starszych (Mk 7,1-5). 
przedstawia pierwszych powołanych jako uczniów Jana Chrzciciela. Z tego wynika, że Teofylakt wykorzystuje w swoim komentarzu do poszczególnych perykop treści pochodzące nie tylko z samej Ewangelii Marka, ale również z innych Ewangelii, jak w tym przypadku z Czwartej Ewangelii (J 1,35). To pominięcie możliwych odniesień do Jana Chrzciciela może mieć swoje źródło w różnicy tekstu, który wykorzystany jest w Wyjaśnieniu. Teofylakt posługuje się tekstem bizantyjskim, którego fragment o wychodzących do Jana sugeruje, iż nauczanie Jana Chrzciciela nie było skierowane do wszystkich mieszkańców Jerozolimy (zob. komentarz do Mk 1,4-5).

Wzmianka o Janie Chrzcicielu pojawia się w komentarzu do relacji o opiniach na temat Jezusa. Tekst ten tworzy - $\mathrm{z}$ następującą po nim narracją $\mathrm{o}$ aresztowaniu i śmierci Jana - kompozycję o złożonej strukturze. Relacja o opiniach może być traktowana jako wprowadzenie do opowiadania o śmierci Jana. Za tym połączeniem przemawia kompozycja warstwowa ${ }^{26}$ (A: Mk 6,6b-13; B: Mk 6,14-29; A’ Mk 6,30-31). Większość wydań Pisma Świętego oraz komentatorów, kierując się motywami literackimi (jedność narracyjna 6,17-29), rozdziela prezentację opinii o Jezusie od narracji o śmierci Jego Prekursora. Złożona struktura literacka musiała także stanowić pewien problem dla Teofylakta. Komentuje on dyskutowany tekst, dzieląc go na trzy fragmenty (Mk 6,14-16; 6,17-20; 6,21-29). Wzmianki o Janie Chrzcicielu pojawiają się we wszystkich, dlatego biskup Ochrydy poświęca mu uwagę w wyjaśnieniach każdego z tych fragmentów.

W pierwszym fragmencie (zawierającym opinie o Jezusie) Teofylakt koncentruje się na roli Heroda i jego sądach o Janie Chrzcicielu. Tekst Marka mówi kolejno o identyfikacji Jezusa: przez Heroda, że jest Janem, przez innych, że jest Eliaszem albo jakimś prorokiem, a kończy się wyznaniem Heroda o jego odpowiedzialności za śmierć Prekursora. Natomiast Teofylakt akcentuje powody, dla których Jezus został przez Heroda utożsamiony z Chrzcicielem. Na koniec charakteryzuje postawę władcy względem Jezusa identyfikowanego ze zmarłym Janem. Takie zakończenie wyjaśnienia dobrze wprowadza do relacji o śmierci Jana.

\subsection{Mk $6,17-20$}

W opowiadaniu o aresztowaniu i śmierci Jana Chrzciciela, które w Ewangelii Marka stanowi narracyjną całość, Teofylakt wyodrębnia dwie części. Ko-

26 W Zakładzie Teologii Biblijnej Starego i Nowego Testamentu Wydziału Teologicznego UŚ powstaje rozprawa doktorska na ten temat. Marcin Moj bada teksty Ewangelii Marka, których narracja charakteryzuje się budową warstwową. 
mentując pierwszą część, zwraca uwagę na to, że ta całość stanowi wtrącenie w opowiadanie o działalności Jezusa. W samym komentarzu wspomina Jana dwukrotnie: na początku i na końcu. Na początku nazywając perykopę opowiadaniem o śmierci Jana, a na końcu charakteryzując stosunek Heroda do Jana jako odnoszenie się z szacunkiem i bojaźnią, które jednak nie zmieniło postępowania władcy. Teofylakt pomija w komentarzu wzmiankę o śmiertelnej wrogości, jaką żywiła Herodiada do Jana Chrzciciela.

Należy zwrócić uwagę, że Teofylakt akcentuje większą (albo nawet wyłączną) odpowiedzialność Heroda za śmierć Jana. Ten nacisk odpowiada kierunkowi interpretacji następnego fragmentu.

\subsection{Mk 6,21-29}

Druga, obszerniejsza część opowiadania o śmierci Jana, wyodrębniona przez Teofylakta, jest objaśniona dość zwięźle. W pierwszej wzmiance o nim otrzymuje tytuł Sprawiedliwy. Druga wzmianka, bardziej szczegółowa, znajduje się na końcu komentarza do tej perykopy, kiedy Teofylakt alegorycznie przedstawia taniec córki Herodiady przed Herodem oraz ścięcie i pogrzeb Jana.

Zaraz na początku Teofylakt przypisuje odpowiedzialność za śmierć Jana Chrzciciela działaniu szatana (przez tańczącą dziewczynę) oraz nieprawości samego Heroda, akcentując jego rozwiązłość. W alegorycznej interpretacji tej sceny Herod jest symbolem Żydów. Córka Herodiady, tańcząca przed władcą i zwodząca go, przedstawia błędne rozumienie Pisma, tańczące i poruszające się wśród Żydów, zwodzące ich, przez co błędnie myślą, że znają Pisma. Alegorycznie interpretowana jest również śmierć Jana i pochowanie jego ciała przez uczniów.

Jedynym elementem nierozwiniętym przez Teofylakta w kierunku alegorycznym, a wprowadzonym przez niego w sensie dosłownym, jest inicjatywa szatana zwodzącego tańcem. Sam czasownik, użyty przez Teofylakta, oznaczający zwodzenie $(\pi \lambda \alpha \nu \hat{\alpha} \nu)$ Żydów przez błędne interpretacje, jest często używany w nowotestamentowych kontrowersjach między Jezusem a Żydami (Mk 12,24.27 - przeciw saduceuszom; J 7,12.47 - przeciw Jezusowi). W tych sporach oznacza albo fałszywe rozumienie Pisma, albo oszukiwanie ludu w kwestiach mesjańskich. Można przypuszczać, że Teofylakt z powodu takiego wykorzystania tego czasownika posługuje się nim w alegorycznej interpretacji tańca podczas uczty Heroda.

Dalej Teofylakt wskazuje na przyczynę błędnych interpretacji. Nie jest nią tyle samo poddanie się działaniu szatana, ile stosunek Żydów do Chrystusa przedstawiony w alegorycznym wyjaśnieniu śmierci i pogrzebu Jego Prekursora. 
Jan jest nazwany słowem prorockim. Żydzi nie przyjęli głowy proroctwa, czyli Chrystusa. Stąd teraz, nawet jeśli mają prorockie słowo, to jest ono pozbawione głowy, czyli Chrystusa. Teofylakt mocno uwydatnia to, że głową proroctwa jest Chrystus. Oryginalne w tym porównaniu nie jest przedstawienie Chrystusa jako głowy (Ef 1,22; Kol 1,18), ale ukazanie Jego relacji do proroków na przykładzie alegorycznej interpretacji śmierci Jana jako związku głowy $\mathrm{z}$ ciałem.

\subsection{Mk $8,27-30$}

Teofylakt wyodrębnia scenę przedstawiającą Jezusa pytającego uczniów o opinie ludzi na Jego temat oraz o ich własny sąd w kwestii Jego tożsamości. Wśród różnych odpowiedzi dawanych przez ludzi, a referowanych przez uczniów, znajduje się utożsamienie Jezusa $\mathrm{z}$ Janem Chrzcicielem.

Biskup Ochrydy wiąże powstanie identyfikacji Jana i Jezusa $z$ opinią podzielaną przez Heroda. Teofylakt przypomina przyczynę utożsamienia Jezusa z Janem powstałym z martwych. Była nią wieść o działalności cudotwórczej w Galilei osoby, o której Herod sądził, że jest nią zmartwychwstały Jan. Wcześniej bowiem Prorok nie czynił żadnych cudów, ale w przekonaniu władcy posiadł taką moc dzięki powstaniu z martwych.

\subsection{Mk 9,11-13}

Kolejna wzmianka o Janie Chrzcicielu w komentarzu Teofylakta do Marka pojawia się w wyjaśnieniu perykopy, która nie wspomina wyraźnie imienia Jana. Schodzący z góry przemienienia są adresatami nakazu milczenia ograniczonego do czasu powstania z martwych Syna Człowieczego. Uczniowie odczytują ten nakaz jako zapowiedź bliskości powszechnego zmartwychwstania ciał, które, zgodnie z przytoczoną przez nich doktryną uczonych w Piśmie, miało być poprzedzone przyjściem Eliasza ${ }^{27}$. Nakaz milczenia oraz odpowiedź Jezusa na wątpliwości uczniów należą do spójnej literacko i teologicznie sceny. Jednak Teofylakt podzielił tę perykopę na dwa fragmenty. Pierwszy zawiera nakaz milczenia nałożony na uczniów oraz ich wątpliwości odnośnie do znaczenia zmartwychwstania (Mk 9,9-10). Drugi natomiast składa się z pytania uczniów o doktrynę uczonych w Piśmie na temat przyjścia Eliasza oraz z odpowiedzi Jezusa na to pytanie (Mk 9,11-13). Chociaż więc w Ewangelii Marka nie jest bezpośrednio wspomniany Jan, to jednak Teofylakt, zgodnie z intencją Ewan-

27 Ta doktryna ma swoje źródło w interpretacji Ml 3,23. 
gelisty, identyfikuje Eliasza poprzedzającego pierwsze przyjście Syna Człowieczego z Janem będącym Prekursorem Jezusa.

W komentarzu Teofylakta do tego fragmentu pojawiają się dwie wzmianki o Janie Chrzcicielu. W pierwszej wskazuje on na cechy łączące Jana i Eliasza, które oddaje przez terminy funkcjonujące prawie jak tytuły: "ganiący”

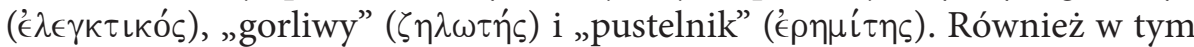
przypadku na pierwszym miejscu wymienia cechę odpowiadającą działalności proroków, którzy przez krytykę postępowania adresatów ich aktywności wzywali do nawrócenia oraz narażali się na prześladowania. Temu charakterowi działalności Jana odpowiada sens drugiej wzmianki Teofylakta przedstawiającego metaforycznie stosunek Żydów do śmierci Jana. Prorok ten stał się dla nich po ścięciu „trofeum w zabawie” ( $\pi \alpha \iota \gamma \nu$ íou "€́ $\pi \alpha \theta \lambda o \nu$ ). Można w tym skojarzeniu widzieć aluzję do wyprowadzenia Samsona przez Filistynów w celu zabawy (w Sdz 16,27 występuje rzeczownik $\pi \alpha \iota \gamma \nu i \alpha$, który określa szydercze rozrywki Filistynów, w których bohater izraelski jest rodzajem ich zdobyczy). Tego paralelizmu biskup Ochrydy jednak nie wskazuje wyraźnie.

\subsection{Mk 11,27-33}

Komentarz Teofylakta obejmuje narrację przedstawiającą pytanie członków sanhedrynu o władzę Jezusa oraz Jego pytanie o pochodzenie chrztu Janowego. Bezpośrednio z tą sceną łączy się przypowieść o rolnikach $\mathrm{w}$ winnicy ( $\mathrm{Mk}$ 12,1-9) oraz jej wyjaśnienie z przedstawieniem reakcji słuchaczy (Mk 12,1012). Jednak Teofylakt komentuje te fragmenty osobno, nie zauważając, że właściwym zakończeniem sceny rozpoczętej od pytania członków sanhedrynu jest informacja o ich wrogiej reakcji na nauczanie Jezusa.

W tekście Marka pada pytanie członków sanhedrynu o pochodzenie władzy Jezusa. Warunkuje On udzielenie odpowiedzi, mówiąc, że wpierw oni powinni odpowiedzieć na postawione przez Niego pytanie o pochodzenie chrztu Jana. Członkowie sanhedrynu jednak nie odpowiadają. Ewangelista przedstawia przyczynę braku tej odpowiedzi przez prezentację skrytych rozważań przywódców ludu zakłopotanych pytaniem Jezusa.

Teofylakt w komentarzu do tej sceny wyjaśnia związek między pytaniem zadanym przez członków sanhedrynu a pytaniem zadanym przez Jezusa. W skazuje, że Jan dawał świadectwo o Chrystusie. Dlatego uznanie pochodzenia jego świadectwa od Boga oznaczało przyjęcie Jezusa jako Mesjasza zapowiadanego przez Jana. Teofylakt interpretuje aktywność Jana przede wszystkim jako dawanie świadectwa. Uwydatnienie tego wymiaru zgadza się z określaniem go głównie jako proroka. 
W komentarzu do samej przypowieści Teofylakt identyfikuje wysłanych przez właściciela winnicy z prorokami. Wymienia niektórych z nich: Micheasza oraz anonimowych proroków w czasach Ozeasza i Izajasza, a następnie Daniela i Ezechiela. Choć w całym komentarzu Teofylakt akcentował prorocką misję Jana, w tym miejscu nie wylicza go wśród wymienionych proroków. Mógłby odnieść wzmiankę o uderzeniu w głowę jednego z wysłanników właściciela winnicy (Mk 12,4) do Jana, który został ścięty. Nie czyni tego jednak, ponieważ wysłannik zraniony w ten sposób nie reprezentuje ostatniego proroka poprzedzającego wysłanie Syna. Takim prorokiem dla Teofylakta jest Jan, co zostało zaakcentowane już w komentarzu do pierwszych wersetów Ewangelii.

\subsection{Mk 13,21-26}

Ostatnia wzmianka o Janie pojawia się w komentarzu do mowy eschatologicznej Jezusa (Mk 13). W tekście biblijnym nie występuje żadne odniesienie do Jana. Także w komentarzu Teofylakta wspomniany jest on jakby mimochodem. Teofylakt analizuje znaczenie wyrażenia „w tamtych dniach”. Przytacza tekst z Pierwszej Ewangelii: „W tamtych dniach pojawił się Jan” (Mt 3,1).

Rozważania Teofylakta odnoszące się do znaczenia tego wyrażenia dowodzą nie tylko uważnej lektury tekstów biblijnych, ale również są dowodem na jego kompetencję filologiczną.

\section{Konkluzje}

Analiza fragmentów Wyjaśnienia odnoszących się do Jana Chrzciciela pomaga dostrzec rysy tej postaci uwydatnione przez Teofylakta, które można uporządkować w czterech grupach. Pierwsza odnosi się do znaczenia Jana dla czytelnika Ewangelii Marka. Druga obejmuje cechy istotne dla jego relacji do Jezusa. Trzecia przedstawia relacje do pojedynczych osób (Herod) i grup ludzi. Czwarta wskazuje na jego wyjątkowe miejsce w kontekście całego Wyjaśnienia.

\subsection{Jan znaczący dla czytelnika Ewangelii}

Teofylakt akcentuje pierwszą z cech proroków: przepowiadanie. Już w komentarzu do pierwszego zdania Ewangelii Marka: „Początek Ewangelii Jezusa Chrystusa, Syna Boga”, Teofylakt oryginalnie utożsamia początek z Janem, a jednocześnie uważa go za reprezentanta wszystkich dotychczasowych proroków, a więc za zakończenie czy zwieńczenie całej wcześniejszej historii zwią- 
zanej z ich aktywnością. Biskup Ochrydy zwraca na to uwagę nie tylko w komentarzu do Mk 1,1-3. Także w Przedmowie, rozróżniając charakterystyczne dla Ewangelistów wątki otwierające narracje o Jezusie, dwukrotnie zaznacza: Marek rozpoczął/rozpoczyna od Jana. Najpierw porównuje Ewangelie Mateusza i Marka. Tryb oznajmujący aorystu „rozpoczął” ("’ $\rho \alpha \tau o)$ jest użyty dla zestawienia ze sobą pierwszych wersetów tych pism ukazujących wydarzenia umieszczone w przeszłości: w pierwszej z nich - narodziny Jezusa, a w drugiej początek - działalności Jana. Natomiast trybem oznajmującym czasu teraźniejszego „rozpoczyna” ( $\propto \chi € \epsilon \alpha \iota)$ posługuje się w porównaniu Marka z Łukaszem, kiedy zamyka przedmowę wezwaniem do słuchania skierowanym do współczesnego czytelnika. Sformułowany w tym miejscu apel stanowi przejście do komentarza tekstu Ewangelii Marka przedstawianego fragment po fragmencie. Od czytelnika tego komentarza Teofylakt oczekuje nie tylko dostrzeżenia specyfiki Ewangelii Marka na tle innych Ewangelii, lecz przede wszystkim uświadomienia sobie jej wagi dla osobistego życia. Takie powiązanie doktryny z parenezą odpowiada pierwszemu nauczaniu Jezusa tej Ewangelii, które składa się z dwóch części: ogłoszenia wypełnienia czasu i bliskości królestwa Bożego oraz wezwania do trwałego nawracania się oraz do wiary w Ewangelię Bożą (Mk $1,15)$.

\subsection{Jan w relacji do Jezusa}

Biskup Ochrydy przedstawia znaczenie prorockiej misji Jana na konkretnych treściach nauczania Chrzciciela. Przepowiadanie (czy też: zapowiadanie) ma swoją treść. Jan jest nazwany początkiem Ewangelii Syna Boga, ogłaszającym i objawiającym przychodzącego Chrystusa. To on przygotował drogę Pana, a jego obecność wskazuje na przybliżanie się Chrystusa. Mówiąc o tej bliskości nie zaciera granicy między dwoma etapami dziejów zbawienia, ale ją starannie przedstawia. W jego analizie są zauważalne elementy analizy narracyjnej. Rozróżnia on między aktywnością Jana a działalnością zapowiadanego przez niego. Biskup Ochrydy nie popełnia błędu często spotykanego jeszcze dzisiaj w wielu komentarzach, który polega na utożsamianiu udzielanego przez Jana chrztu wodą z chrztem nawrócenia na odpuszczenie grzechów $(\mathrm{Mk} 1,4)^{28}$. Teofylakt stwierdza dobitnie, że głoszony przez Jana chrzest nawrócenia nie ma mocy odpuszczania grzechów, ale ma przygotowywać na przyjęcie Chrystusa. Jezus

28 Por. A. Malina, Chrzest Jezusa w czterech, s. 173. Błędnie utożsamiają chrzest udzielany przez Jana z chrztem głoszonym przez niego m.in.: S. Grasso, Vangelo di Marco, s. 44; S. Légasse, Marco, s. 67; M. Mullins, The Gospel of Mark, s. 62; F.J. Moloney, The Gospel of Mark, s. 35. 
przychodzi na chrzest, „by został objawiony przez Jana ludowi”. Na przykładzie tej konkluzji, sformułowanej w drugim fragmencie Wyjaśnienia (do Mk 1,4-5), można zauważyć, że Teofylakt wiąże ze sobą nawet interpretowane oddzielnie perykopy Ewangelii. Komentując rodzącą problemy chrystologiczne relację o chrzcie Jezusa przyjętym od Jana, odwołuje się do wcześniej sformułowanej konkluzji o ograniczonych celach chrztu Jana i słusznie zauważa, że Chrystus nie mógł przyjąć Ducha Świętego w Jordanie ani odpuszczenia grzechów nie tyle z tego powodu, że Ducha Świętego już posiadał, albo dlatego, że nie miał grzechów, ile dlatego, że chrzest udzielany przez Jego Prekursora miał jedynie przygotować ludzi na przyjęcie odpuszczenia grzechów oraz umożliwić objawienie Go ludowi.

Widać więc wyraźnie, w jaki sposób Teofylakt przedstawia swoje rozumienie relacji Jana do Jezusa. Jest on prorokiem, bezpośrednio poprzedzającym przyjście Mesjasza. Jego głoszenie Przychodzącego jest skierowane do przychodzących po chrzest nawrócenia, aby byli gotowi przyjąć Chrystusa.

\subsection{Jan $w$ relacji do ludzi}

W głoszeniu chrztu nawrócenia ujawnia się druga cecha proroków akcentowana przez Teofylakta: wzywanie do nawrócenia. Biskup Ochrydy przedstawia dwie aktywności Jana jako sobie odpowiadające: udzielanie chrztu na pustyni i głoszenie chrztu nawrócenia. Adresatami tej działalności - zgodnie z rozpowszechnioną wersją tekstu bizantyjskiego, z której korzystał Teofylakt - są mieszkańcy krainy judzkiej, choć nie wszyscy mieszkańcy Jerozolimy. Zależność od tekstu bizantyjskiego - w wielu miejscach Ewangelii Marka - dość różniącego się od lepiej poświadczonych lekcji przez kodeksy typu aleksandryjskiego wpłynęła na spostrzeżenia Teofylakta. Nie mógł on dostrzec na przykład, że adresaci działalności Jana Chrzciciela, jakimi są wszyscy mieszkańcy Jerozolimy, musieli się znaleźć wśród adresatów słów i czynów Jezusa. Zapewne z tego powodu, kiedy wyjaśnia znaczenie osoby i dzieła Chrzciciela dla ludzi, częściej posługuje się interpretacją alegoryczną niż analizą sensu wyrazowego.

Przykładem takiej egzegezy jest komentarz do wersetu charakteryzującego sposób życia Chrzciciela. Ubiór i pożywienie Jana mają wartość symbolicznych czynności prorockich skierowanych do adresatów jego działalności. Strój Jana jest symbolem żałoby, aby pokazywał, że zadaniem nawracających się jest zasmucenie. Natomiast jego pokarm ma kierować uwagę mieszkańców krainy judzkiej ku wstrzemięźliwości. Jako przeciwną tym cnotom ukazuje Teofylakt postawę Heroda.

Prorocy, krytykując postępowanie adresatów swojej działalności i wzywając ich do nawrócenia, narażali się na prześladowania z ich strony. Nie inaczej 
jest z Janem, którego śmierć Teofylakt odczytuje najpierw jako naigrywanie się Żydów z samego Prekursora (który, po ścięciu, stał się dla nich „trofeum w zabawie"). W śmierci i pogrzebie Jana biskup Ochrydy widzi także świadectwo stosunku Żydów do Chrystusa. Nieprzyjęcie treści głoszonych przez Jana i ścięcie go odczytuje jako odrzucenie Głowy proroctwa, czyli Chrystusa. Widać tu wyraźnie, że Teofylakt odczytuje wszystkie proroctwa w jednym, chrystologicznym kluczu. Działalność wszystkich proroków, spośród których Jan był ostatnim, miała prowadzić do przyjęcia Głowy - Chrystusa.

\subsection{Jan w Ewangelii Marka}

Teofylakt zauważa, że treść narracji o Janie Chrzcicielu jest charakterystyczna dla Ewangelii Marka. W Przedmowie zaznacza, że jego obraz w Marku odróżnia się od jego przedstawienia w pozostałych Ewangeliach. Najpierw w porównaniu z samym Mateuszem, potem w zestawieniu ze wszystkimi Ewangeliami. Komentując poszczególne fragmenty Drugiej Ewangelii przywołuje Jana nawet w tych perykopach, w których nie pojawia się on wyraźnie.

Prymat Jana nie jest absolutny, ale podporządkowany najważniejszemu protagoniście Ewangelii. Konsekwentnie bowiem interpretuje osobę i działalność Jana w kluczu prorockim. On jest tym, który zapowiada Przychodzącego i wzywa do nawrócenia. To dzięki łasce prorokowania widzi wyraźnie rzeczy odległe, jak je dostrzega orzeł symbolizujący Ewangelię Marka. Wreszcie to Jan Prekursor wskazuje na Chrystusa, treść Ewangelii.

\section{Bibliografia}

Apokryfy Nowego Testamentu, t. 1: Ewangelie apokryficzne, red. M. Starowieyski, Lublin 1986.

Czarnuch M., Papuga Złotoustego? Teofylakt z Ochrydy jako komentator Ewangelii Mar$k a$, w: Szkice o antyku, red. A. Kucz, Katowice 2014 [w druku].

Czarnuch M., Teofylakta uzasadnienie „Wyjaśnienia do Ewangelii Marka”, Śląskie Studia Historyczno-Teologiczne 46,2 (2013) [w druku].

Gnilka J., Das Evangelium nach Markus, Zürich 1978.

Gnilka J., Marco, Assisi 1987.

Grasso S., Vangelo di Marco, Milano 2003.

Grundmann W., Das Evangelium nach Markus, Berlin 1971.

Gundry R.H., Mark. A Commentary on His Apology for the Cross, Grand Rapids 1992.

Head P.M., The Early Text of Mark, w: The Early Text of the New Testament, red. Ch.E. Hill, M. J. Kruger, Oxford 2012, s. 108-120.

Hendriksen W., The Gospel of Mark, Edinburgh 1975. 
Langkammer H., Ewangelia według św. Marka. Wstęp - przekład z oryginału - komentarz, Poznań 2007 (reprint z 1977).

Légasse S., Marco, Roma 2000.

Malina A., Chrzest Jezusa w czterech Ewangeliach. Studium narracji i teologii, Katowice 2007.

Malina A., Jezus i księgi Nowego Testamentu o aniołach, w: Aniołowie w życiu ludzi, red. A. Żądło, Katowice 2009, s. 19-37.

Mateos J., Camacho D., Il Vangelo di Marco, Assisi 1997.

Mullins M., The Gospel of Mark, Dublin 2005.

Moloney F.J., The Gospel of Mark, Peabody 2002.

Neirynck F., Commentaries Before 1950. Patristic and Medieval Commentaries (in chronological order), w: The Gospel of Mark. A Cumulative Bibliography. 1950-1990, red. F. Neirynck, Leuven 1992, s. 701-717.

Novum Testamentum Graece, red. B. Aland, K. Aland, J. Karavidopoulos, C.M. Martini, B.M. Metzger, Stuttgart $2012^{28}$.

Oden T.C., Hall C.A., Wprowadzenie do Komentarza, w: Ewangelia według św. Marka, red. [pol. wyd.] L. Misiarczyk, Ząbki 2009, s. XIX-XXIX.

Oden T.C., Hall C.A., Wstęp ogólny, w: Ewangelia według św. Marka, red. [pol. wyd.] L. Misiarczyk, Ząbki 2009, s. VII-XII.

Rodd C.S., The Gospel of Mark, Peterborough 2005.

Saunders E.W., Theophylact of Bulgaria as Writer and Biblical Interpreter, Biblical Research 2 (1957), s. 35.

Stock A., The Method and Message of Mark, Wilmington 1988.

Stock K., Marco, Roma $2010^{3}$. 